\title{
The Role of New Members of Phytohormones in Plant Amelioration under Abiotic Stress with an Emphasis on Heavy Metals
}

\author{
Abolghassem Emamverdian ${ }^{1,3}$, Yulong Ding ${ }^{1,3 *}$, Yinfeng Xie ${ }^{1,2}$ \\ ${ }^{1}$ Co-Innovation Center for Sustainable Forestry in Southern China, Nanjing Forestry University, Nanjing, China \\ ${ }^{2}$ College of Biology and the Environment, Nanjing Forestry University, Nanjing, China \\ ${ }^{3}$ Bamboo Research Institute, Nanjing Forestry University, Nanjing, China
}

Received: 27 February 2019

Accepted: 22 April 2019

\begin{abstract}
In addition to regulating plant growth and development, phytohormones play an essential role in the response to abiotic and biotic stress - especially heavy metal stress. In response to environmental stressors, phytohormones act as signaling molecules in both exogenous and endogenous signaling pathways. In parts of the rhizosphere, phytohormones have an exogenous role, and when regulating plant growth and development, they have an endogenous role. Phytohormones and their associated signaling pathway network are involved in plant responses to heavy metal stress. These molecules can improve the plant defense system by increasing antioxidant enzyme activity and degrading lipoperoxidation and $\mathrm{H}_{2} \mathrm{O}_{2}$. Phytohormones are divided into classical phytohormones such as auxins, ethylene, gibberellins, and cytokinins, that have been investigated for many years and the new members, such as jasmonates, brassinosteroids, and strigolactones, which have been little studied. In this review article, we investigated the main mechanisms involved in the amelioration of heavy metals by the three new phytohormones to provide more knowledge about their detoxification mechanisms.
\end{abstract}

Keywords: abiotic stress, heavy metals, jasmonates, brassinosteroids, strigolactones

\section{Introduction}

Phytohormones, as a signaling molecule, regulate endogenous plant growth, as well as influence the metabolism and physiological processes of a plant [1]. Plants have adapted to biotic and abiotic stresses with the mediating role of phytohormone in the regulation of stress [2-4]. Phytohormones alter their levels upon the encounter with abiotic stress, such as heavy metal

*e-mail: ylding@vip.163.com stress [1, 5]. Phytohormones are the vital components of complicated signaling networks in the current stress response models, which include salicylic acid (SA), ethylene (Et), abscisic acid (ABA) [6], and the new members jasmonic acid (JA), brassinosteroids (BRs), and strigolactones (SLs) [7]. Phytohormones are known as a regulator of plant growth and development and play an important role in response to abiotic and biotic stresses [8]. They are a small molecule with low concentration, but play an important role as a chemical messenger in the regulation of cells in plants [9]. There are two categories of phytohormones, which 
are classical phytohormones such as auxins, ethylene, gibberellins, and cytokinins, and the new members such as jasmonates, brassinosteroids, and strigolactones [7], which are discussed in this article. Strigolactones (SLs) are a member of the new phytohormone group, which are involved in important plant processes including seed germination, as well as the development of roots and plant architecture, which are exudates from roots [10]. Brassinosteroids are another new phytohormone member, which are reported to be involved in many cell cycle processes, cellular expansion and plant differentiation [11]. Jasmonic acid is also a small molecule that belongs to the new phytohormone group that plays an important role in plant growth and development and the reduction of stress [12]. In this review, we investigate the identification of these new Phytohormones and the mechanisms involved in the reduction of heavy metal stress by their applications.

\section{Mechanisms Involved in New Phytohormones}

When plants encounter oxidative stress, plant resistance is increased by the stimulation of antioxidant activities. If the antioxidants are inadequate to cope with the stresses, plants increase their resistance by the enhancement of various signaling molecules via exogenous treatment [13, 14]. Alternatively, plants can also alter endogenous levels of phytohormones in response to stressful conditions [15]. It has been reported that phytohormones, including ABA, JAs, Et and salicylic acid, are involved in the signaling pathways that can play an important role in crosstalk of the stresssignaling pathways [16]. Additionally, phytohormones are involved in signaling pathways, which shows that JAs play an essential role in the activation of the pathway that is involved in signal transduction [17]. In phytohormones, signaling pathways have a vital role in the reduction of purposeful proteins through the ubiquitin-proteasome [18]. The phytohormones are also known to interact with each other to ameliorate the stress conditions [19]. Crosstalk between ABA and SLs is involved in the regulation of stress signaling, which improves stomatal efficiency [20]. The SKP1CULLIN-F-BOX complex (SCF) is a major element in the signaling pathway of phytohormones [21]. Also, the development of the root and shoot result from the crosstalk between IAA and SLs [22, 23]. Additionally, every phytohormone and its signals have an F-box protein component that belongs to the $S C F$, and its binding with the target protein results in its degradation [24]. The mechanisms reported for the binding of SLs with target F-box proteins include binding via Skp1 [21]. Data obtained from genetic analyses of SL-insensitive mutants in A. thaliana and rice revealed three pathways that are involved in SL signal transduction, which include a repressor and receptor that belong to the SCF complex, namely the D53/SMXL6 repressor to 8,
D14/DAD2 receptor and F-box protein (MAX2/D3) [25, 26]. The complex of SCF reducing the repressor with proteasome-mediation can be the main mechanism of phytohormones in the adjustment of gene expression [27]. Below are the mechanisms of new phytohormones and signaling pathway networks for scavenging of ROS and metal stress.

\section{Jasmonates (JAs) Via Heavy Metal Stress}

Jasmonates (JAs) represent a new class of phytohormones. Jasmonates belong to cyclopentanone compounds, and in the octadecanoic pathway they are synthesized by linolenic acid. Jasmonates have two recognized forms: methyl jasmonate (MeJA) and jasmonic acid (JA) [28]. As a signaling molecule, $\mathrm{MeJA}$ is a part of cyclopentanone compounds that play an important role in stress conditions by acting as a signal transduction pathway [29]. In the JA signaling network, MeJA and JA are bioactive small molecules that are indicated by the isoleucine conjugated jasmonyl derivative [30]. MeJA is responsible for gene expression that leads to increased plant cell resistance in stress conditions. Hanaka et al. [31] conducted research on the enhancement of endogenous levels of MeJA in response to different stressors, especially heavy metal stress [30,31]. Methyl jasmonate mediates the regulation of metabolism and is involved in gene expression in responses to stress, cell communication, activation of plant defense mechanisms, and plant growth and development [32]. These molecules can increase the production of biomass and reduced malondialdehyde content and fluorescence in leaf chlorophyll following the exposure of plants to heavy metals; they can also reduce oxidative stress induced by reactive oxygen species (ROS) by degrading ROS derivatives such as $\mathrm{OH}$ and $\mathrm{H}_{2} \mathrm{O}_{2}$ in leaves, and control transcriptional pathways through oxidative stress [33]. There are two hypotheses regarding how JA can reduce $\mathrm{H}_{2} \mathrm{O}_{2}$ and MDA. The first one is related to antioxidant activity; with increasing antioxidant activity, JA leads to scavenging of ROS derivatives and reduces $\mathrm{H}_{2} \mathrm{O}_{2}$ production in cells. These changes lead to degradation of $\mathrm{H}_{2} \mathrm{O}_{2}$ and MDA in cells. The second hypothesis is related to another endogenous phytohormone. JA can induce other phytohormones for scavenging of ROS generated by oxidative stress in plants [34]. Many studies have shown that applying jasmones (JA) can ameliorate complete (Chl) content under heavy metal stress, which has been reported in many plants, including soybean [35], capsicum frutescens and Kandelia obovata [28]. Therefore, JA can preserve a pigment system in photosynthesis and with increasing $\mathrm{Chl}$ content can enhance chlorophyll biosynthesis and ultimately prevent the damaging impact of ROS on cell membrane structures such as chloroplast [36]. Jasmonates (JAs) play an essential role in stress-signaling networks in plants under abiotic and biotic stresses [12] by acting as a signaling molecule involved in the rising resistance to stress 
via the activation of related genes [37]. The protective role of JA against the stress of heavy metals involves stimulation of antioxidant enzymes, reduction of $\mathrm{H}_{2} \mathrm{O}_{2}$ and malondialdehyde (MDA) (protection of the cell membrane lipids), and providing a protective role for photosynthetic pigments (reducing oxidative damage) [38]. This protective role is indicated by the effect of $0.1 \mu \mathrm{mol} \mathrm{L}-1 \mathrm{JA}$ on Wolffia arrhiza under Pb stress [39] and by the effect of $10 \mu \mathrm{mol} L-1$ MeJA on soybeans under Cd stress [40]. The results obtained for the effect of $0.1 \mu \mathrm{mol} \mathrm{L}-1 \mathrm{JA}$ on Wolffia arrhiza under Pb stress show that JA protects the plant by increasing the level of primary metabolites, which help to restore plant growth, prevent $\mathrm{Pb}$ accumulation in the plant, and activate plant defense mechanisms (enzymatic and nonenzymatic activities), including POD, CAT, NADH peroxidase, glutathione, and ascorbate [39]. JA can also reduce translocation of heavy metals from the root to the shoot, which prevents the accumulation of heavy metals in plants. This reduced translocation was confirmed by the effect of the Cd on K. obovata [28] and by the effect of $\mathrm{Pb}$ on $\mathrm{W}$. arrhiza [28, 39]; however, it occurs at a low concentration of JA (JA at $0.1 \mu$ mol $\mathrm{L}^{-1}$ ), which indicates the role of JA concentration in the amelioration of heavy metals [39]. A previous study showed that $\mathrm{Cd}^{2+}$ MeJA with a low concentration of JA maintained plant membrane degradation and helped rice seedlings under stress [41]. Methyl jasmonate also regulates stimulation of stomatal closure, leading to an effective role in plant transpiration [28, 42], which can reduce metal uptake in the shoot and xylem sap [43], hence reducing the loading of heavy metals in the xylem and shoot [44]. Jasmonates can be elevated in response to heavy metal stress as a one-second messenger when the plant defense mechanism is stimulated [37]. This process is related to the stimulation of antioxidant activity [35]. A previous study investigating the effect of the $\mathrm{Cd}$ on Capsicum frutescens var. fasciculatum seedlings showed that under $\mathrm{Cd}$, a low concentration of methyl jasmonate exposes the plant to increased antioxidant activity, such as SOD and CAT, in the leaf, decreases MDA concentrations and lipoperoxidation [35]. Additionally, APX in rice [17] and increased GR in rice seedlings indicate that MeJA is a protective tool to cope with the damaging effects of oxidative stress [41]. In other studies, exogenous methyl jasmonate (MeJA) increased the activity of antioxidant enzymes (APX and CAT), and reduced MDA and lipoperoxidation in Kandelia obovate. It was also reported that MeJA prevents $\mathrm{Cd}$ accumulation in leaves, which occurs because of the influence on stomatal closure and reduction of transpiration by exogenous methyl jasmonate (MeJA). And it can show other aspects of the jasmonate mechanism in the face of heavy metal stress [28]. In particular, it was reported by Keramat et al. (2009) that the effect of 10 to $100 \mu \mathrm{mol} \mathrm{L}-1$ JA on the soybean plant (Glycine max L.) increased antioxidant activity, such as SOD, APX, and CAT, under Cd stress [40]. There is not an exact explanation for how exogenous MeJA acts on antioxidant mechanisms to remove heavy metal stress in intercellular parts of the plant, but scientists have reported that increased accumulation of endogenous JA in intercellular plant organs can be a strong reason for the amelioration of heavy metals in the intercellular parts of plants, which are directly increased by the effect of exogenous MeJA in plants [28-45]. In rice seedlings, exposure to $\mathrm{Cu}$ [46] and exposure of pea plants to Cd [47], as well as exposure of P. coccineus and A. thaliana to $\mathrm{Cd}$ and $\mathrm{Cu}$ [48], resulted in a structural alteration of JA that was dynamic and transient under abiotic stresses [48]. The role of jasmonate signaling on the stimulation of OsDOX gene expression in the stress condition has been previously studied, with the results showing that exogenous MeJA leads to OsDOX expression in the rice shoot, which evoked enhanced reactive oxygen species (ROS) [46]. The Jasmonates signaling pathway that induces $\dot{\alpha}$-dioxygenases (DOXs) (OsDOX gene expression) is a regulation mechanism in response to oxidative stress caused by heavy metals [46]. A previous study showed that MeJA significantly impacts the toxicity of $\mathrm{Cu}$ and $\mathrm{Cd}$ in Arabidopsis plants, which depends on the jasmonic acid concentration and its focus on a specific point (external or internal) [45]. Additionally, studies have shown that gene expression in plant mechanisms, including phytochelatins (PCs) and metallothioneins (MTs), can raise plant resistance under heavy metal stress such that plant MT genes, such as the KoMT2 gene, play an essential role in the degradation of oxidative stress and heavy metal detoxification via the influence on $\mathrm{Cd}$ accumulation in $\mathrm{K}$. obovata leaves [28]. This has been reported in various plants exposed to heavy metals [49-50-51]. Evidence shows that exogenous JA/MeJA can increase synthesis of PCs and MTs at the transcript level during the heavy metal stress condition [28]; however, the exact mechanisms remain unclear and hence require future research.

\section{Brassinosteroids (BRs) Via Heavy Metal Stress}

Brassinosteroids (BRs) as a member of phytosteroidal hormones [11] are known as a new application of plant hormones that belong to the polyhydroxy steroidal group [52-53]. Among the 70 BRs that exist in plants, three types, including 24-epibrassinolide, 28-homobrassinolide and brassinolide, have been underinvestigated in regard to their role in the plant growth and development process because they have been identified as top bioactive brassinosteroids [52-54]. BRs play an important role in many growth processes in plants, including the growth of fruit, flowers, pollen, seeds and fiber, as well as rhizogenesis, abscission, and senescence. They also play a role in the regulation of cellular expansion and plant differentiation, which are conducted by several genes involved in stimulated plant signaling [11]. Further, BRs are involved in many important cell cycle process such as cell division, cell elongation, senescence and vascular differentiation; as such, they are very important for plant growth [55]. Additionally, it is indicated that BRs provide protective 
activity for plants under environmental stress [52]. BRs are involved in the regulation of expression of more than a hundred genes and influence many metabolic pathways that are involved in plant responses to environmental stress [56]. Additionally, BRs have the ability to stimulate antioxidant activity in stress conditions such as heavy metal, drought, and salinity [57]. Brassinosteroids (BRs) can increase plant resistance with some plant defense mechanism, such as the reduction of lipoperoxidation, stimulation of antioxidant activity and improvement of phytochelatin synthesis [52]. Additionally, the efficiency of photosynthesis is improved with the mechanisms involved in the photochemical pathways involving BRs. These mechanisms include amelioration of electron transport efficiency, improved damage of reaction centers and complexes of $\mathrm{O}_{2}$ evolution, which have been reported for winter rape under $\mathrm{Cd}$ stress [58]. Many studies have reported that BRs can decrease heavy metal stress in plants [52-59-60]. In plants exposed to heavy metals, BRs as a regulator play an essential role in the morphogenetic and physiological responses that can reduce biotic and abiotic stresses [61]. BRs can also reduce the accumulation and uptake of heavy metals, which was shown in a study on Brassica juncea seeds exposed to $\mathrm{Cu}$, where the results indicated that BRs improved shoot and biomass production and decreased the accumulation and uptake of copper in plants [62]. The results of previous studies have indicated that BR has a strong impact on plant growth and biomass, which was specifically reported for mung beans exposed to aluminum stress [56-63]. BR also plays a vital role in the regulation of the elongation of shoots and roots, as well as seed germination [64]. Exogenous BRs can scavenge ROS compounds with mechanisms such as stimulation of antioxidants and accumulation of $\mathrm{H}_{2} \mathrm{O}_{2}$, which can improve plant resistance to oxidative stress caused by heavy metals [52]. BRs preserve the regulation of the cellular redox state by adjusting and stimulating antioxidant enzymes such as SOD, CAT, DHAR, MDHAR GR and APOX, which maintain the cell membrane and cell integrity by decreasing phospholipid peroxidation or the accumulation of osmoprotectant [52]. It is not clear how BRs can protect the cell, but BRs regulate protein and enzyme activity in the membrane and interact with sterols and proteins in the membrane [65]. Thus, the BR1 encoded protein complex (leucine-rich repeat receptor-like kinase) that is conducted through the signaling network by related genes can regulate plant responses to stress [66]. Therefore, BRs can regulate the expression of various genes responsible for encoding plant defense mechanisms including phytochelatins (PCs), antioxidant enzymes [60-67] and metallothioneins (MTs) [52]. BRs can facilitate and stimulate the syntheses of phytochelatins (PCs) in the plant cell in heavy metal stress conditions, which has been reported in plants exposed to $\mathrm{Pb}$ [68]. PCs are cysteine-rich compounds with the ability of metal binding, which plays an important role in the compartmentalization of metal in vacuoles or the chelation of metal in the cytosol [52]. Bioabsorption of metals is another mechanism that can degrade heavy metals. It occurs by metals-linking in deference mechanisms including chemical and physical adsorption, as well as complexation and ion exchange, which involve a process where metals interact with hydroxyl, carboxyl, phosphoryl and amino groups. Further, the $\mathrm{pH}$ of the solution plays an important role in removing the metals, with an optimum $\mathrm{pH}$ between 4-6 [69]. Brassinosteroids can reduce $\mathrm{pH}$ in the cell wall and help plant growth, which has been reported in C. vulgaris [68]. Additionally, BRs can influence water deficits. A previous study reported that excess $\mathrm{Cd}$ alters the biological function of the membrane in cell wall so that it has reduced capacity to maintain its water stage, leading to a water deficit in the plant [70]. However, BRs were found to improve the leaf water potential and ameliorated water deficits in the plant [70]. It has also been reported that BRs improve the levels of pigments/ carotenoids (reduction of $\beta$-carotene and lycopene) in ripening fruits exposed to $\mathrm{Cd}$ heavy metals, which indicates a positive role of BRs in the photosynthesis process [70].

\section{Strigolactones (SLs) Via Heavy Metal Stress}

Strigolactones (SLs) are known as new plant hormones (Phytohormones) [71-72-73], and they play a role in root architecture, rhizosphere structure and seed germination in parasitic plants [2-74-75-76]. It has also been reported that SLs are involved in the senescence of the leaf [77], reaction to nutrient stress [78-79], response to biotic stress [80], regulation of the development of roots [81-82], and development and branching of shoots; they also play a signaling role in the interaction between plants [73]. In this signaling role, SLs are referred to as rhizosphere signaling molecules [83-84] because in the rhizosphere, Strigolactones are involved in detection signals in plant roots and fungi [85]. The generation of strigolactones (SLs) usually occurs in roots and some stem parts; however, they flow and are secreted in the rhizosphere and are then involved in biosynthesis throughout the plant, although this amount is minimal [86-87]. The pathways of CL biosynthesis occur in the plastid, and during the transferring process (ring closures, oxidation, and functionalizations in the membrane), it moves into the cytoplasm [88]. Recently, caprolactone (CL) has been identified as one of the intermediates in the biosynthesis of SLs and SL-like compounds [89-90-91]. There are more than 1000 SLs in nature; however, only 19 SLs have yet been identified [92-93]. Generally, SLs play a coordinating role in the regulation of below- and above-ground plant architecture, senescence of the leaf, root and shoot formation, reproductive development and secondary growth in plants [94-95-96-97]. Strigolactones (SLs) have been identified as a multifunctional molecule of new phytohormones that can play an important role in improving plant development when exposed 
to stress and deficient conditions. Phytohormones are very important for phosphorus deficiencies and nutrient shortages [98]. Strigolactones (SLs) play an important role in plant mechanisms against water and nutrient deficiencies [99-100], and can be linked with abiotic stresses such as nutrients and metals [78]. The mechanism of strigolactones in the encounter with metals and nutrients are bilateral, which is related to the structure and architecture of the root system [73]. A previous study on $\mathrm{Pi}$ (an inorganic form of phosphorus) reported that strigolactones can regulate root systems by improving development of lateral root formation with a suitable concentration of $\mathrm{Pi}$ and conversely inhibit the emergence of lateral roots with a high concentration of $\mathrm{Pi}$. Thus, reducing the uptake of heavy metals in the plant by decreasing the length and density of root hairs is one of the avoidance mechanism of strigolactones for coping with heavy metals [95-101]. Recent research has confirmed the role of strigolactones (SLs) on the LR (latest root) formation process, which occurs in synthetic strigolactone stages [27]. In roots, SLs are responsible for altering actin dynamics, and the structure of the plasma membrane involved in the displacement of the transporter of PINFORMED auxin [7], with rising degradation speed of PIN-FORMED1 (PIN 1) [22]. There are 15 types of strigolactones that have been introduced and identified by researchers, which have been analyzed in a variety of studies [102]. The biosynthesis of strigolactones has been conducted in all parts of the plants [73], especially in the later parts of the stem and root [87], but usually a small amount is generated in the primary roots of all varieties of plants, including single plant species and primitive plants (Charales and Embryophyta) [73], which is transferred to the apex shoot vertically (to acropetally) [103]. It has also been reported that symbiotic arbuscular mycorrhizal fungi (AM) and root-parasitic plants are classic sites for strigolactones (SLs) as rhizospheric hosts [104]. Carotenoid synthesis is the only pathway that is known to be involved in strigolactones biosynthesis. It is controlled with three plastid-localized proteins [105] that begin with changes of all-trans- $\beta$-carotene into carlactone (CL). Previous studies investigating essential proteins in SL signaling and biosynthesis on mutant species, including Oryza sativa L. Petunia hybrida, Pisum sativum L, and Arabidopsis thaliana L [106], have reported that this process occurs with alteration in a cytochrome P450 monooxygenase class III case by enhancement in growth of AXILLARY GROWTH1 (MAX1) [107-108]. The role of enzymes of carotenoid cleavage dioxygenase (CCD) in different species of plants [109] is demonstrated by the essential roles of CCD7 and CCD8 in SL synthesis [71-72]. Strigolactone structures include one enol ether that plays the linking role between two ring systems, including the butenolide $\mathrm{D}$ and $\mathrm{ABC}$ ring [86]. These molecules have some signaling pathways that include interactions between protein structure and degradation of the ubiquitin-dependent repressor [74]. The SL mutants, including the SL signaling mutant $\max 2$ and SL biosynthesis mutants max4 and max3, comprise the link between SL and ABA phytohormones, which are more sensitive to drought stress conditions with the regulation of the stomata [110-20]. Additionally, the root and shoot of branching strigolactones (SLs) play an essential role in cellular redox homeostasis. It has been shown that mutant formation (ore9) is involved in MAX2 and could prevent senescence and oxidative stress in comparison with wildtype [111]. GR24, a synthesized strigolactone, is known to be a defense mechanism in stress conditions. Exogenous GR24 leads to increasing plant tolerance against salt and drought stress in Arabidopsis [74-20]. When placed in the root access, it is transferred to the shoots [19-112], creating a positive role in coping with stress [101]. A previous experiment found that GR24 reduced MDA content and chloroplast damage and increased the photosynthetic capacity and plant defense mechanism against ROS with the stimulation of antioxidant enzyme activity (SOD and POD) caused by salinity stresses [1]. Additionally, SLs have the ability to regulate the development of shoot branching in plants, which can be a positive mechanism to cope with the adverse effect of heavy metals on shoot branching. Additionally, SLs prevent shoot branching caused by heavy metal modulation, auxin transport and their biosynthesis processes by which the involved metal levels can regulate shoot branching and increase plant biomass. Further, SLs are involved in the regulation of the development root and root hairs, which can ameliorate the negative effect of nutrients and heavy metals, including calcium (Ca), N, Iron (Fe), sulfur (S), $\mathrm{Pi}$, and aluminum (Al), on root development process such as primary root elongation, lateral root initiation, and root-hair formation [113]. Low concentrations of some metals, including $\mathrm{N}$ and $\mathrm{Pi}$, leads to increased SLs in plant roots; thus, it has been reported that SLs can enhance root-hair length and root-hair elongation and consequently improve nutrient absorption in plants [114].

Strigolactones (SLs) are known as signaling molecules that are involved in the response to environment stress [23]. Furthermore, SLs act as both exogenous and endogenous signaling molecules in response to environmental stresses [115]. Thus, SLs act exogenously in parts of the rhizosphere and endogenously as phytohormones that regulate plant growth and development [115]. SLs have been reported as signaling pathways in several species, including pea, petunia, Arabidopsis, and rice [86], which can regulate plant development and interactions between the plant and the environment [71-72]. There is also evidence that the signaling pathways of SLs and auxin are involved in the adjustment of root architecture, which is influenced by GSH. Specifically, there is a signaling link between SLs, auxin and GSH that prevents GSH synthesis and degradation of the adverse role of GSH on the root structure [116]. 
Table 1. Impact of new phytohormones on different species under various heavy metals by describing the involved mechanisms.

\begin{tabular}{|c|c|c|c|c|c|}
\hline Plant & $\begin{array}{l}\text { Heavy metal } \\
\text { stress }\end{array}$ & $\begin{array}{l}\text { Applications of new phy- } \\
\text { tohormones }\end{array}$ & $\begin{array}{l}\text { Impact } \\
\text { on stress }\end{array}$ & Mechanism & Reference \\
\hline $\begin{array}{l}\text { Indian mustard } \\
\text { (Brassica juncea) }\end{array}$ & $\mathrm{Cu}$ & BRs & + & $\begin{array}{c}\text { Inhibition from accumulation and uptake } \\
\text { of copper and aid in shoot generation } \\
\text { and biomass }\end{array}$ & {$[62]$} \\
\hline $\begin{array}{l}\text { Radish (Raphanus } \\
\text { sativus L.) }\end{array}$ & $\mathrm{Zn}$ & BRs & + & $\begin{array}{c}\text { Enhancement of photosynthetic } \\
\text { pigments-reduction of } \mathrm{H}_{2} \mathrm{O}_{2}, \mathrm{Lp} \text { and, } \\
\text { electrolyte leakage (ELP)- increasing } \\
\text { catalase (SOD), (CAT), (APX) - (ASA), } \\
(\mathrm{GSH}), \text { and proline }\end{array}$ & [117] \\
\hline $\begin{array}{l}\text { Radish (Raphanus } \\
\quad \text { sativus L.) }\end{array}$ & $\mathrm{Zn}^{2+}$ & $\begin{array}{l}\text { 28-Homobrassinolide } \\
\text { (HBR) }\end{array}$ & + & $\begin{array}{l}\text { Increasing in phytochelatins (PCs)- } \\
\text { increasing enzyme activities of GSH } \\
\text { metabolism (GR, GPX and GST) and } \\
\text { GSH biosynthesis ( } \gamma \text {-ECS and GS) and } \\
\text { reduction of MDA and H2O2 }\end{array}$ & [118] \\
\hline $\begin{array}{l}\text { Tomato cultivars } \\
\text { (cv. K-25 and Sar- } \\
\text { vodya) }\end{array}$ & $\mathrm{Cd}$ & \begin{tabular}{|c|} 
28-homobrassinolide \\
(HBL) or 24-epibrassino- \\
lide (EBL)
\end{tabular} & + & $\begin{array}{c}\text { Improving photosynthetic perform- } \\
\text { ance- increasing antioxidant activity and } \\
\text { proline content }\end{array}$ & [119] \\
\hline $\begin{array}{l}\text { Bean (Phaseolus } \\
\text { vulgaris L.) }\end{array}$ & $\mathrm{Cd}$ and $\mathrm{Nacl}$ & 24-epibrassinolide (EBL) & + & $\begin{array}{c}\text { Enhancement of antioxidative enzymes } \\
\text { and proline-improving water content and } \\
\text { the membrane stability index (MSI) }\end{array}$ & {$[120]$} \\
\hline $\begin{array}{l}\text { Radish (Raphanus } \\
\quad \text { sativus L.) }\end{array}$ & $\mathrm{Cd}$ & $\begin{array}{l}\text { 24-epibrassinolide and } \\
\text { 28-homobrassinolide }\end{array}$ & + & $\begin{array}{c}\text { Increasing antioxidant enzymes activity } \\
\text { including SOD, CAT, GPX, and APOX- } \\
\text { the reduction of lipid peroxidation }\end{array}$ & [121] \\
\hline $\begin{array}{l}\text { Tomato cultivars } \\
\text { (K-25 and } \\
\text { Sarvodya) }\end{array}$ & $\mathrm{Cd}$ & $\begin{array}{c}\text { 28-homobrassinolide/24- } \\
\text { epibrassinolide (HBL/ } \\
\text { EBL) }\end{array}$ & + & $\begin{array}{c}\text { Improving photosynthetic and the in- } \\
\text { creasing antioxidant enzyme activity and } \\
\text { proline content }\end{array}$ & {$[122]$} \\
\hline Tomato & $\mathrm{Cd}$ & Brassinosteroid & + & Increasing antioxidant activity & {$[70]$} \\
\hline $\begin{array}{l}\text { Brassica napus } \mathrm{L} . \\
\text { cultivars (ZS 758-a } \\
\text { black seed type, and } \\
\text { Zheda } 622-\text { a yellow } \\
\quad \text { seed type) }\end{array}$ & As & Methyl jasmonate (MJ) & + & $\begin{array}{c}\text { Increasing gene expression and enzy- } \\
\text { matic activities (POD, SOD, APX, CAT, } \\
\text { CAD, PPO, and PAL). Degradation of } \\
\text { As contents }\end{array}$ & {$[33]$} \\
\hline Maize seedlings & $\mathrm{Na}_{2} \mathrm{CO}_{3}$-stress & Jasmonic acid (JA) & + & $\begin{array}{c}\text { Reduction of uptake of } \mathrm{Na} \text { and } \mathrm{Na} 2 \mathrm{CO} 3- \\
\text { induced oxidative damage by degrada- } \\
\text { tion of ROS accumulation and malondi- } \\
\text { aldehyde }\end{array}$ & [123] \\
\hline $\begin{array}{l}\text { Mustard (Brassica } \\
\text { juncea } \mathrm{L} .)\end{array}$ & $\mathrm{Cd}$ & Methyl jasmonate (MeJA) & + & $\begin{array}{c}\text { Enhancement of S-assimilation and } \\
\text { production of decreasing glutathione } \\
\text { (GSH) and ameliorated of functions in } \\
\text { photosynthetic }\end{array}$ & [124] \\
\hline $\begin{array}{l}\text { Faba bean (Vicia } \\
\quad \text { faba L.) }\end{array}$ & $\mathrm{Cd}$ & Jasmonic acid (JA) & + & $\begin{array}{c}\text { Increasing antioxidant activity SOD, } \\
\text { CAT, glutathione reductase and ascorbate } \\
\text { peroxidase Accumulation of Cd in } \\
\text { shoots, roots, and leaves }\end{array}$ & {$[125]$} \\
\hline Arabidopsis plants & $\mathrm{Cu}$ and $\mathrm{Cd}$ & Jasmonic acid (JAMe) & + & $\begin{array}{c}\text { Influence on chlorophyll efficiency and } \\
\text { photosynthetic activity }\end{array}$ & {$[45]$} \\
\hline $\begin{array}{l}\text { Soybean plant (Gly- } \\
\quad \text { cine } \max \mathrm{L} .)\end{array}$ & $\mathrm{Cd}$ & Methyl jasmonate & + & $\begin{array}{c}\text { Decreasing of } \mathrm{H} 2 \mathrm{O} 2 \text { and MDA content } \\
\text { and enhancement of antioxidant enzymes } \\
\text { activity }\end{array}$ & [40] \\
\hline Foxtail millet & $\mathrm{Cd}$ & Methyl jasmonate & + & $\begin{array}{c}\text { MeJA ameliorated Cd stress by medi- } \\
\text { ated of endogenous sodium hydrosulfide } \\
\left(\mathrm{H}_{2} \mathrm{~S}\right)\end{array}$ & [126] \\
\hline $\begin{array}{l}\text { Switchgrass (Pani- } \\
\text { cum virgatum) }\end{array}$ & $\mathrm{Cd}$ & $\begin{array}{c}\text { Exogenous synthetic SLs } \\
\text { analog, } \\
\text { GR24 }\end{array}$ & + & $\begin{array}{l}\text { Reducing Cadmium uptake-activation of } \\
\text { activities of antioxidant enzymes }\end{array}$ & {$[127]$} \\
\hline
\end{tabular}


Table 1. Continued.

\begin{tabular}{|c|c|c|c|c|c|}
\hline Brassica napus $L$ & $\mathrm{NaCl}$ & $\begin{array}{l}\text { GR24, a synthesized strig- } \\
\text { olactone }\end{array}$ & + & $\begin{array}{l}\text { Gene expression regulation related to } \\
\text { plant defense mechanism, signal trans- } \\
\text { duction of phytohormones and increas- } \\
\text { ing photosynthesis }\end{array}$ & {$[10]$} \\
\hline $\begin{array}{l}\text { Rice (Oryza sativa } \\
\text { L) }\end{array}$ & $\begin{array}{l}\text { Phosphate and } \\
\text { Nitrate }\end{array}$ & SL analogue GR24 & + & $\begin{array}{c}\text { Regulation of development of rice root, } \\
\text { which is faced with nitrate and phos- } \\
\text { phate and limitation }\end{array}$ & [128] \\
\hline $\begin{array}{l}\text { Pea (Pisum sativum } \\
\text { L.) }\end{array}$ & $\begin{array}{l}\text { Phosphate and } \\
\text { Nitrate }\end{array}$ & Strigolactone synthesis & + & $\begin{array}{l}\text { Regulates development of mycorrhizal } \\
\text { and regulates of nodulation in roots }\end{array}$ & [129] \\
\hline $\begin{array}{l}\text { Arabidopsis (Arabi- } \\
\text { dopsis thaliana) }\end{array}$ & $\begin{array}{l}\text { Phosphate } \\
\text { deficiency }\end{array}$ & Strigolactone production & + & $\begin{array}{l}\text { The adjustment of shoot architectural } \\
\text { in the face to phosphate deficiency with } \\
\text { xylem-transported strigolactones }\end{array}$ & [130] \\
\hline Arabidopsis & $\begin{array}{l}\text { Low Pi condi- } \\
\text { tions }\end{array}$ & $\begin{array}{l}\text { synthetic strigolactone } \\
\text { GR24 }\end{array}$ & + & $\begin{array}{c}\text { Transmitted via the MAX2 component } \\
\text { of SL signaling }\end{array}$ & [131] \\
\hline Rice seedlings & $\begin{array}{l}\text { Phosphate }(\mathrm{Pi}) \\
\text { and nitrate }\end{array}$ & Strigolactones (SLs) & + & $\begin{array}{l}\text { First as a signal of rhizosphere to maxi- } \\
\text { mize AM fungi symbiosis for improved } \\
\text { Pi acquisition and the second one is the } \\
\text { endogenous hormone or its biosynthetic } \\
\text { precursor to optimizing shoot branching } \\
\text { for efficient Pi utilization }\end{array}$ & [132] \\
\hline
\end{tabular}

\section{Discussion}

The identification and determination of detoxification factors to reduce heavy metal stress can be a good option for coping with this harmful stress. Among these factors are phytohormones, which play an important role in plant growth and development and the cell cycle process in plants and can help to reduce heavy metal stress. These small molecules can regulate stress signaling through signaling pathway networks in plants and can improve plant defense systems by increasing antioxidant enzyme activity and degrading lipoperoxidation and $\mathrm{H}_{2} \mathrm{O}_{2}$. There are two categories of phytohormones, which consist of classical phytohormones such as auxins, ethylene, gibberellins, and cytokinins, and the newest members of phytohormones such as strigolactones, brassinosteroids, and jasmonates. Jasmonic acid (JA) is an important member of the plant growth regulator (PGR) family, which can act as a signaling molecule in plants exposed to heavy metal stress. JA acts as signaling molecules involved in the rising resistance to stress by activation of related genes. The protective role of JA against the stress of heavy metals involves the stimulation of antioxidant enzymes, reduction of $\mathrm{H}_{2} \mathrm{O}_{2}$ and malondialdehyde (MDA) (to protect the cell membrane lipid) and providing a protective role for photosynthetic pigments (reducing oxidative damage). SLs are defined as a new class of multifunctional phytohormone molecules that are produced by plant root exudation and play an important role in some process involved in plant growth, including seed germination, the formation of the root and hypocotyl growth. SLs play an important role in plant mechanisms against water and nutrient deficiencies and can be linked with abiotic stresses such as nutrients and meals. The mechanisms of SLs when faced with metals and nutrients are bilateral, which is related to the structure and architecture of the root system. In addition to root and shoot branching, SLs play an essential role in cellular redox homeostasis. It has been shown that compared with wildtype formation, mutant formation (ore9), which is involved in MAX2, could prevent senescence and oxidative stress. GR24, a synthesized strigolactone, is known to be a defense mechanism in stress conditions. Exogenous GR24 leads to increased plant tolerance against salt, drought and metal stress, reduced MDA content and chloroplast damage, and increased photosynthetic capacity and plant defense mechanisms against ROS via stimulation of antioxidant enzyme activity (SOD and POD) caused by salinity stresses. Additionally, SLs have the ability to regulate the development of shoot branching in plants, which can be a positive mechanism for coping with the adverse effects of heavy metals on shoot branching. Brassinosteroids (BRs), as a new group of phytohormones, are involved in many growth processes in plants including growing of the fruit, flower, pollen, seed, and fiber, as well as rhizogenesis, abscission, and senescence. Additionally, BRs have a role in the regulation of cellular expansion and plant differentiation. Brassinosteroids (BRs) can improve plant resistance with some plant defense mechanisms such as the reduction of lipoperoxidation, stimulation of antioxidant activity and improving phytochelatin synthesis. Brassinosteroids also improve photosynthesis efficiency via mechanisms involved in photochemical pathways and ameliorate electron transport efficiency to improve damage of reaction centers and evolving complexes of $\mathrm{O}_{2}$. Furthermore, BRs can regulate the expression of a variety of genes encoding plant defense mechanism including PC, antioxidant enzymes and metallothioneins. Brassinosteroids can also facilitate and stimulate the synthesis of PC in the plant cell 
in heavy metal stress conditions. Phytochelatins are cysteine-rich compounds with the ability of metal binding, which play an important role in the compartmentalization of metal in vacuoles or chelation of metals in the cytosol. This review has described the existing mechanisms and summarizes the findings of several studies that have described the positive effects of these new phytohormones on heavy metal stress, as mentioned below. Table 1 explains the impact of new phytohormones on different species under various heavy metals by describing the involved mechanisms.

\section{Perspective}

The signaling pathways networks involved in phytohormones play an essential role in regulating the integrity of plants coping with stress. These networks regulate and stimulate gene expression related to plant defense systems, such as antioxidant activities, phytochelatins (PCs), metallothioneins (MTs) and other pathways. Despite numerous studies, ambiguous issues remain, for example how exogenous JA/MeJA can increase the synthesis of PCs and MTs at a transcript level during heavy metal stress conditions. Additionally, we know that BR is a regulated protein that interacts with enzyme activity in the membrane and with sterols and proteins in membranes. However, it remains unknown how BRs can protect the cell and which mechanisms are involved in BR efficiency in aiding plant cells in oxidative stress. Thus, this questions should be considered in future studies. In this review, we have tried to examine the available mechanisms against the stresses of heavy metals in new hormones by synthesizing information from recent research. This review will provide a broader concept of the understanding of these hormones in future studies. Hopefully, in the future, we will gain more knowledge and an understanding of the mechanisms involved in this area.

\section{Acknowledgements}

This work was supported by Nationl Key Research \& Development Program of China (Intergration and Demonestration of Valued \& Efficinency - increased Technology across the Industry Chain For bamboo, 2016 YFD0600901).

\section{Conflict of Interest}

The authors declare that there is no conflict of interests regarding the publication of this paper.

\section{References}

1. IQBAL N., UMAR S., KHAN N.A., KHAN M.I.R. A new perspective of phytohormones in salinity tolerance: regulation of proline metabolism. Environ. Exp. Bot. 100, 34, 2014.

2. VAN ZEIJL A., LIU W., XIAO T.T., KOHLEN W., YANG W., BISSELING T. The strigolactone biosynthesis gene DWARF27 is co-opted in rhizobium symbiosis. BMC Plant Biol. 15, 260, 2015.

3. CHEN Z., GAO X., ZHANG J., BONFANTE P., GENRE A., AL-BABILI S. Strigolactones affect lateral root formation and root-hair elongation in Arabidopsis. Planta. 6, 209, 2015.

4. PANDYA-KUMAR N., SHEMA R., KUMAR M., MAYZLISH-GATI E., LEVY D., ZEMACH H. Strigolactone analog GR24 triggers changes in PIN2 polarity, vesicle trafficking and actin filament architecture. New Phytol. 202, 1184, 2014.

5. DOGANLAR Z.B. Physiological and genetic responses to pesticide mixture treatment of Veronica beccabunga. Water, Air Soil Pollut. 223, 6201, 2012.

6. EGAMBERDIEVA D., WIRTH S.J., ALQARAWI A.A., ABD_ALLAH E.F., HASHEM A. Phytohormones and Beneficial Microbes: Essential Components for Plants to Balance Stress and Fitness. Front Microbiol. 8, 2017.

7. WANI S.H., KUMAR V., SHRIRAM V., KUMAR SAH S. Phytohormones and their metabolic engineering for abiotic stress tolerance in crop plants, Crop J. 4, 162, 2016.

8. PELEG Z., BLUMWALD E. Hormone balance and abiotic stress tolerance in crop plants. Curr. Opin. Plant Biol. 14, 290, 2011.

9. VOB U., BISHOPP A., FARCOT E., BENNETT M.J. Modelling hormonal response and development. Trends Plant Sci. 19, 311, 2014.

10. MA N., HU C., WAN L., HU Q., XIONG J., ZHANG C. Strigolactones Improve Plant Growth, Photosynthesis, and Alleviate Oxidative Stress under Salinity in Rapeseed (Brassica napus L.) by Regulating Gene Expression. Front. Plant Sci. 2017.

11. BHARDWAJ R., SHARMA I., KAPOOR D., VANDANA P., GAUTAM V., KAUR R., BALI S., SHARMA A. Brassinosteroids: Improving Crop Productivity and Abiotic Stress Tolerance. In: Ahmad P., Wani M. (eds) Physiological Mechanisms and Adaptation Strategies in Plants Under Changing Environment. Springer, New York, NY, 2014.

12. OKADA K., ABE H., ARIMURA G.I. Jasmonates Induce Both Defense Responses and Communication in Monocotyledonous and Dicotyledonous Plants. Plant Cell Physiol. 56 (1), 16, 2015.

13. QIU Z., GUO J., ZHU A., ZHANG L., ZHANG M. Exogenous jasmonic acid can enhance tolerance of wheat seedlings to salt stress.Ecotoxicol. Environ. Saf. 104, 202, 2014.

14. KADIOGLU A., SARUHAN N., SAĞLAM A., TERZI R., ACET T. Exogenous salicylic acid alleviates effects of long term drought stress and delays leaf rolling by inducing antioxidant system. Plant Growth Regul. 64, 27, 2011.

15. KAYA A., DOGANLAR Z.B. Exogenous jasmonic acid induces stress tolerance in tobacco (Nicotiana tabacum) exposed to imazapic. Ecotoxicol Environ Saf. 124, 470, 2016.

16. ZHANG S., DENG Y.Z., ZHANG L.H. Phytohormones: the chemical language in Magnaporthe oryzae-rice pathosystem. Mycology. 9 (3), 233, 2018.

17. SINGH I., SHAH K. Evidences for structural basis of altered ascorbate peroxidase activity in cadmium-stressed 
rice plants exposed to jasmonate. Biometals, 27, 247, 2014b.

18. WANG C., LIU Y., LI S.S., HAN G.Z. Insights into the origin and evolution of the plant hormone signaling machinery. Plant Physiol. 167, 872, 2015a .

19. KHOSLA A., NELSON D.C. Strigolactones, super hormones in the fight against Striga. Curr. Opin. Plant Biol, 33, 57, 2016.

20. HA C.V., LEYVA-GONZALEZ M.A., OSAKABE Y., TRAN U.T., NISHIYAMA R., WATANABE Y., TANAKA M., SEKI M., YAMAGUCHI S., VAN DONG N., YAMAGUCHI-SHINOZAKI K., SHINOZAKI K., HERRERA-ESTRELLA L., PHAN TRAN L.S. Positive regulatory role of strigolactone in plant responses to drought and salt stress. Proc Natl Acad Sci U S A. 111, 851, 2014.

21. LARRIEU A., VERNOUX T. Comparison of plant hormone signalling systems. Essays Biochem, 58, 165, 2015.

22. SHINOHARA N., TAYLOR C., LEYSER O. Strigolactone can promote or inhibit shoot branching by triggering rapid depletion of the auxin efflux protein PIN1 from the plasma membrane. PLOS Biol. 11, e1001474, 2013.

23. DOMAGALSKA M.A., LEYSER O. Signal integration in the control of shoot branching. Nat. Rev. Mol. Cell Biol. 12, 211, 2011.

24. LÓPEZ-RÁEZ J.A. How drought and salinity affect arbuscular mycorrhizal symbiosis and strigolactone biosynthesis? Planta. 243, 1375, 2016.

25. HAMIAUX C., DRUMMOND R.S., JANSSEN B.J., LEDGER S.E., COONEY J.M., NEWCOMB R.D., SNOWDEN K.C. $\mathrm{DAD}_{2}$ is an $\alpha / \beta$ hydrolase likely to be involved in the perception of the plant branching hormone, strigolactone. Curr Biol 6. 22, 2032, 2012.

26. ARITE T., UMEHARA M., ISHIKAWA S., HANADA A., MAEKAWA M., YAMAGUCHI S., KYOZUKA J.D. A strigolactone-insensitive mutant of rice, shows an accelerated outgrowth of tillers. J Plant Cell Physiol. 50, 1416, 2009.

27. WANG L., WANG B., JIANG L., LIU X., LI X., LU Z., MENG X., WANG Y., SMITH S.M., LI J. Strigolactone Signaling in Arabidopsis Regulates Shoot Development by Targeting D53-Like SMXL Repressor Proteins for Ubiquitination and Degradation. J Plant Cell. 27, 3128, 2015.

28. CHEN J., YAN ZH., LI X. Effect of methyl jasmonate on cadmium uptake and antioxidative capacity in Kandelia obovata seedlings under cadmium stress. Ecotoxicol Environ Saf. 104, 349, 2014.

29. SANTINO A., TAURINO M., DE DOMENICO S., BONSEGNA S., POLTRONIERI P., PASTOR V., FLORS V. Jasmonate signaling in plant development and defense response to multiple (a)biotic stresses. Plant Cell Rep. 32, 1085, 2013.

30. WASTERNACK C., HAUSE B. Jasmonates: biosynthesis, perception, signal transduction and action in plant stress response, growth and development. An update to the 2007 review in Annals of Botany. Ann Bot. 111, 1021, 2013.

31. HANAKA A., MAKSYMIEC W., BEDNAREK W. The effect of methyl jasmonate on selected physiological parameters of copper-treated Phaseolus coccineus plants. Plant Growth Regul. 77, 167, 2015.

32. SOARES A.M.S., DESOUZA T.F., JACINTO T., MACHADO O.L.T. Effect of methyl jasmonate on antioxidative enzyme activities and on the contents of
ROS and $\mathrm{H}_{2} \mathrm{O}_{2}$ in Ricinus communis leaves. Braz. J. Plant Physiol. 22, 151, 2010.

33. FAROOQ M.A., GILL R.A., ISLAM F., ALI B., SHU J., LIU H., HE S., ZHOU W. Methyl Jasmonate Regulates Antioxidant Defense and Suppresses Arsenic Uptake in Brassica napus L. Front Plant Sci.. 7, 2016.

34. KANG D.J., SEO Y.J., LEE J.D., ISHII R., KIM K.U., SHIN D.H. Jasmonic acid differentially affects growth, ion uptake and abscisic acid concentration in salt-tolerant and salt-sensitive rice cultivars. J. Agron. Crop Sci. 191, 273, 2005.

35. YAN Z., CHEN J., LI X. Methyl jasmonate as modulator of $\mathrm{Cd}$ toxicity in Capsicum frutescens var. fasciculatum seedlings. Ecotoxicol. Environ. Saf. 98, 203, 2013.

36. SHARMA P., KAUR H., SIRHINDI G. Effect of Jasmonic Acid on Photosynthetic Pigments and Stress Markers in Cajanus cajan (L.) Millsp. Seedlings under Copper Stress. Am J Plant Sci. 04 (04). 2013.

37. AHMAD P., RASOOL S., GUL A., SHEIKH S.A., AKRAM N.A., ASHRAF M., KAZI A.M., GUCE S. Jasmonates: Multifunctional Roles in Stress Tolerance. Front Plant Sci. 7, 813, 2016.

38. KOVÁČIK J., KLEJDUS B., ŠTORK F., HEDBAVNY J., BAČKOR M. Comparison of methyl jasmonate and cadmium effect on selected physiological parameters in Scenedesmus quadricauda (chlorophyta, chlorophyceae). J. Phycol. 47, 1044, 2011.

39. PIOTROWSKA A., BAJGUZ A., GODLEWSKAŻYŁKIEWICZ B., CZERPAK R., KAMIŃSKA M. Jasmonic acid as modulator of lead toxicity in aquatic plant Wolffia arrhiza (Lemnaceae).Environ. Exp. Bot. 66, 507, 2009.

40. KERAMAT B., KALANTARI K.M., ARVIN M.J. Effects of methyl jasmonate in regulating cadmium induced oxidative stress in soybean plant (Glycine $\max$ L.).Afr. J. Microbiol. Res. 3, 240, 2009.

41. SINGH I., SHAH K. Exogenous application of methyl jasmonate lowers the effect of cadmium-induced oxidative injury in rice seedlings. Phytochemistry. 108, 57, 2014.

42. HOSSAIN M.A., MUNEMASA S., URAJI M., NAKAMURAY., MORI I.C., MURATA Y. Involvement of endogenous abscisic acid in methyl jasmonate-induced stomatal closure in Arabidopsis. Plant Physiol. 156, 430, 2011.

43. KANWAR M.K., BHARDWAJ R., ARORA P., CHOWDHARY S.P., SHARMA P., KUMAR S. Plant steroid hormones produced under $\mathrm{Ni}$ stress are involved in the regulation of metal uptake and oxidative stress in Brassica juncea L.Chemosphere. 86, 41, 2012.

44. LUX A., MARTINKA M., VACULÍK M., WHITE P.J. Root responses to cadmium in the rhizosphere: a review. J. Exp. Bot. 62, 21, 2011.

45. MAKSYMIEC W., KRUPA Z. Jasmonic acid and heavy metals in Arabidopsis plants - a similar physiological response to both stressors?, J. Plant Physiol. 159, 509, 2002.

46. KOEDUKA T., MATSUI K., HASEGAWA M., AKAKABEA Y., KAJIWARA T. Rice fatty acid -dioxygenase is induced by pathogen attack and heavy metal stress: activation through jasmonate signaling. J. Plant Physiol. 162, 912, 2005.

47. RODRIGUEZ-SERRANO M., ROMERO-PUERTAS M.C., PAZMINO D.M., TESTILLANO P.C., RISUENO M.C., DEL RIO L.A., SANDALIO L.M. Cellular response of pea plants to cadmium toxicity: cross talk between 
reactive oxygen species, nitric oxide, and calcium. Plant Physiol. 150, 229, 2009.

48. MAKSYMIEC W., WIANOWSKA D., DAWIDOWICZ A.L., RADKIEWICZ S., MARDAROWICZ M., KRUPA $Z$. The level of jasmonic acid in Arabidopsis thaliana and Phaseolus coccineus plants under heavy metal stress. J. Plant Physiol. 162, 1338, 2005.

49. HUANG G.Y., WANG Y.S. Expression analysis of type 2 metallothionein gene in mangrove species (Bruguiera gymnorrhiza) under heavy metal stress. Chemosphere, 77, 1026, 2009.

50. HUANG G.Y., WANG Y.S. Expression and characterization analysis of type 2 metallothionein from grey mangrove species (Avicennia marina) in response to metal stress. Aquat. Toxicol. 99, 86, 2010.

51. HUANG G.Y., WANG Y.S., YING G.G., DANG A.C. Analysis of type 2 metallothionein gene from mangrove species (Kandelia candel), Trees 22, 1537, 2012.

52. RAJEWSKA I., TALAREK M., BAJGUZ A. Brassinosteroids and Response of Plants to Heavy Metals Action. Front. Plant Sci. 7, 629, 2016.

53. NOVÁKOVÁ O., KUNEŠ I., GALLO J., BALÁŠ M. Effects of brassinosteroids on prosperity of Scots pine seedlings. J. For. Sci. 60 (9), 388, 2014.

54. QUE F., WANG G.L., XU Z.S., WANG F., XIONG A.S. Transcriptional Regulation of Brassinosteroid Accumulation during Carrot Development and the Potential Role of Brassinosteroids in Petiole Elongation. Front. Plant Sci. 2017.

55. WEI Z., LI JIA Brassinosteroids Regulate Root Growth, Development, and Symbiosis. Molecular Plant. 9 (1), 86-, 2016.

56. FARIDUDDIN Q., YUSUF M., AHMAD I., AHMAD A. Brassinosteroids and their role in response of plants to abiotic stresses. Biologia Plantarum. 58, 9, 2014.

57. ANWAR A., LIU Y., DONG R., BAI L., YU X., LI Y. The physiological and molecular mechanism of brassinosteroid in response to stress: a review. Biol Res. 12, 51 (1), 46, 2018.

58. JANECZKO A., KOSCIELNIAK J., PILIPOWICZ M., SZAREK-LUKASZEWSKA G., SKOCZOWSKI A. Protection of winter rape photosystem 2 by 24-epibrassinolide under cadmium stress. Photosynthetica. 43, 293, 2005.

59. CHOUDHARY S.P., VOLKAN ORAL H., BHARDWAJ R., YU J.Q. Interaction of Brassinosteroids and Polyamines Enhances Copper Stress Tolerance in Raphanus Sativus. J Exp Bot. 63 (15), 5659, 2012.

60. SHARMA I., SHARMA A., PATI P., BHARDWAJ R. Brassinosteroids Reciprocates Heavy Metals Induced Oxidative Stress in Radish by Regulating the Expression of Key Antioxidant Enzyme Genes. Braz. arch. biol. Technol. 61 Curitiba. 2018.

61. ARDHINI B.V. Brassinosteroids are potential ameliorators of heavy metal stresses in plants," in Plant Metal Interaction, ed. Ahmad P., editor. (Amsterdam: Elsevier; ), 209, 2016.

62. SHARMA P., BHARDWAJ R., ARORA N., ARORA H.K. Effect of 28-homobrassinolide on growth, zinc metal uptake and antioxidative enzyme activities in Brassica juncea L. seedlings. Braz. J. Plant Physiol, 19, 203, 2007.

63. ALI B., HASAN SA., HAYAT S., HAYAT Q., YADAV S., FARIDUDDIN Q.A. Role for brassinosteroids in the amelioration of aluminum stress through antioxidant system in mung bean (Vigna radiata L. Wilczek). Environ. Exp. Bot. 62, 153, 2008.
64. YUSUF M., FARIDUDDIN Q., AHMAD A. 28-Homobrassinolide mitigates boron induced toxicity through enhanced antioxidant system in Vigna radiata plants. Chemosphere. 85, 1574, 2011.

65. LINDSEY K., PULLEN M.L., TOPPING J.F. Importance of plant sterols in pattern formation and hormone signalling. Trends Plant Sci. 8, 521, 2003.

66. WANG W., BAI M.Y., WANG Z.Y. The brassinosteroid signaling network-a paradigm of signal integration. Curr Opin Plant Biol. 21, 147, 2014.

67. YU M.H., ZHAO Z.Z., HE J.X. Brassinosteroid Signaling in Plant-Microbe Interactions. Int. J. Mol. Sci 19 (12), 4091, 2018.

68. BAJGUZ A. Brassinosteroids and lead as stimulators of phytochelatins synthesis in Chlorella vulgaris. J. Plant Physiol. 159, 321, 2002.

69. GUPTA S., KUMAR D., GAUR J.P. Kinetic and isotherm modeling of lead(II) sorption onto some waste plant materials. Chem. Eng. J. 148, 226, 2009.

70. HAYAT S., ALYEMENI M.N., HASAN S.A. Foliar spray of brassinosteroid enhances yield and quality of Solanum lycopersicum under cadmium stress. Saudi J Biol Sci. 19, 325, 2012

71. GOMEZ-ROLDAN V., FERMAS S., BREWER P.B., PUECH-PAGE'S V., DUN E.A., PILLOT J.P., LETISSE F., MATUSOVA R., DANOUN S., PORTAIS J.C., BOUWMEESTER H., BE'CARD G., BEVERIDGE C.A., RAMEAU C., RO-CHANGE S.F. Strigolactone inhibition of shoot branching. Nature. 455, 189, 2008.

72. UMEHARA M., HANADA A., YOSHIDA S., AKIYAMA K., ARITE T., TAKEDA-KAMIYA N., MAGOME H., KAMIYA Y., SHIRASU K., YONEYAMA K., KYOZUKA J., YAMAGUCHI S. Inhibition of shoot branchingby new terpenoid plant hormones. Nature. $\mathbf{4 5 5}$, 195, 2008.

73. KAPULNIK Y., DELAUX P.M., RESNICK N., MAYZLISH-GATI E., WININGER S., BHATTACHARYA C., SÉJALON-DELMAS N., COMBIER J.P., BÉCARD G., BELAUSOV E., BEECKMAN T., DOR E., HERSHENHORN J., KOLTAI $\mathrm{H}$. Strigolactones affect lateral root formation and roothair elongation in Arabidopsis. Planta, 233, 209, 2011.

74. KAPULNIK Y., KOLTAI H. Strigolactone involvement in root development, response to abiotic stress, and interactions with the biotic soil environment. Plant Physiol. 166, 560, 2014.

75. KOLTAI H, KAPULNIK Y. Unveiling signaling events in root responses to strigolactone. Mol. Plant. 6, 589, 2013.

76. FOO E., REID J.B. Strigolactones: new physiological roles for an ancient signal. J. Plant Growth Regul. 32, 429, 2013.

77. YAMADA Y., UMEHARA M. Possible Roles of Strigolactones during Leaf Senescence. Plants (Basel). 11 (4), 664, 2015.

78. MARZEC M., MUSZYNSKA A., GRUSZKA D. The role of strigolactones in nutrient-stress responses in plants. Int $\mathrm{J}$ Mol Sci. 14, 9286, 2013.

79. SUN H., BI Y., TAO J., HUANG S., HOU M., XUE R., LIANG Z., GU P., YONEYAMA K., XIE X., SHEN Q., XU G., ZHANG Y. Strigolactones are required for nitric oxide to induce root elongation in response to nitrogen and phosphate deficiencies in rice. Plant Cell Environ. 39, 1473, 2016.

80. MARZEC M., MUSZYNSKA A. In silico analysis of the genes encoding proteins that are involved in the biosynthesis of the RMS/MAX/D pathway revealed new 
roles of Strigolactones in plants. Int J Mol Sci. 16, 6757, 2015.

81. SUN H., TAO J., GU P., XU G., ZHANG Y. The role of strigolactones in root development. Plant Signal Behav. 11 (1), e1110662, 2016.

82. KOLTAI H., KAPULNIK Y. Strigolactones involvement in root development and communications, in Root Engineering eds Morte A., Varma A., editors. (Berlin: Springer;) 203, 2014.

83. SAEED W., NASEEM S., ALI Z. Strigolactones Biosynthesis and Their Role in Abiotic Stress Resilience in Plants: A Critical Review. Front Plant Sci. 8, 1487, 2017.

84. MARZEC M. Perception and Signaling of Strigolactones. Front. Plant Sci. 2016

85. CARVALHAIS L.C., RINCON-FLOREZ V., BREWER P.B., BEVERIDGE C.A., DENNIS P.G., SCHENK P.M. The ability of plants to produce strigolactones affects rhizosphere community composition of fungi but not bacteria. Rhizosphere. 9, 18, 2019.

86. XIE X., YONEYAMA K., YONEYAMA K. The strigolactone story. Annu Rev Phytopathol. 48, 93, 2010.

87. DUN E.A., BREWER P.B., BEVERIDGE C.A. Strigolactones: discoveryof the elusive shoot branching hormone. Trends Plant Sci, 14, 364, 2009.

88. ZHANG Y., VAN DIJK A.D.J., SCAFFIDI A., FLEMATTI G.R., HOFMANN M., CHARNIKHOVA T., VERSTAPPEN F., HEPWORTH J., VAN DER KROL S., LEYSER O. Rice cytochrome P450 MAX1 homologs catalyze distinct steps in strigolactone biosynthesis. Nat. Chem. Biol. 10, 1028, 2014.

89. AL-BABILI S., BOUWMEESTER H.J. Strigolactones, a novel carotenoid-derived plant hormone. Annu. Rev. Plant Biol. 66, 161, 2015.

90. ABE S., SADO A., TANAKA K., KISUGI T., ASAMI K., OTA S., KIM H.I., YONEYAMA K., XIE X., OHNISHI T. Carlactone is converted to carlactonoic acid by MAX1 in Arabidopsis and its methyl ester can directly interact with AtD14 in vitro. Proc. Natl. Acad. Sci. USA, 111, 18084, 2014.

91. SETO Y., SADO A., ASAMI K., HANADA A., UMEHARA M., AKIYAMA K., YAMAGUCHI S. Carlactone is an endogenous biosynthetic precursor for strigolactones. Proc. Natl. Acad. Sci. USA 111, 1640, 2014.

92. ĆAVAR S., ZWANENBURG B., TARKOWSKI P. Strigolactones: occurrence, structure, and biological activity in the rhizosphere. Phytochem Rev. 14, 4, 2014.

93. ZWANENBURG B., POSPÍŚIL T. Structure and activity of strigolactones: new plant hormones with a rich future. Mol Plant. 6, 38, 2013.

94. YAMADA Y., FURUSAWA S., NAGASAKA S., SHIMOMURA K., YAMAGUCHI S., UMEHARA M. Strigolactone signaling regulates rice leaf senescence in response to a phosphate deficiency. Planta. 240, 399, 2014.

95. RUYTER-SPIRA C., KOHLEN W., CHARNIKHOVA T., VAN ZEIJL A., VAN BEZOUWEN L., DE RUIJTER N., CARDOSO C., LOPEZ-RAEZ J.A., MATUSOVA R., BOURS R. Physiological effects of the synthetic strigolactone analog GR24 on root system architecture in Arabidopsis: another belowground role for strigolactones? Plant Physiol. 155, 721, 2011.

96. RASMUSSEN A., MASON M.G., DE CUYPER C., BREWER P.B., HEROLD S., AGUSTI J., GEELEN D., GREB T., GOORMACHTIG S., BEECKMAN T., BEVERIDGE C.A. Strigolactones suppress adventitious rooting in Arabidopsis and pea. Plant Physiol. 158, 1976, 2012.

97. KOHLEN W., CHARNIKHOVA T., LAMMERS M., POLLINA T., TOTH P., HAIDER I., POZO M.J., DE MAAGD R.A., RUYTER-SPIRA C., BOUWMEESTER H.J., LÓPEZ-RÁEZ, J.A. The tomato CAROTENOID CLEAVAGE DIOXYGENASE8 (SICCD8) regulates rhizosphere signaling, plant architecture and affects reproductive development through strigolactone biosynthesis. New Phytol. 196, 535, 2012.

98. ANDREO-JIMENEZ B., RUYTER-SPIRA C., BOUWMEESTER H.J., LOPEZ-RAEZ J.A. Ecological relevance of strigolactones in nutrient uptake and other abiotic stresses, and in plant-microbe interactions belowground. Plant Soil. 394, 1, 2015.

99. VISENTIN I., VITALI M., FERRERO M., ZHANG Y., RUYTER-SPIRA C., NOVÁK O. Low levels of strigolactones in roots as a component of the systemic signal of drought stress in tomato. New Phytol. 212, 954, 2016.

100. RUIZ-LOZANO J.M., AROCA R., ZAMARREÑO A.M., MOLINA S., ANDREO-JIMÉNEZ B., PORCEL R., GARCÍA-MINA J.M., RUYTER-SPIRA C., LÓPEZRÁEZ J.A. Arbuscular mycorrhizal symbiosis induces strigolactone biosynthesis under drought and improves drought tolerance in lettuce and tomato. Plant Cell Environ. 39, 441, 2016.

101. COCHETEL N., MÉTÉIER E., MERLIN I., HÉVIN H., POUVREAU J.B., COUTOS-THÉVENOT P., HERNOULD M., VIVIN P., COOKSON S.J., LAUVERGEAT N.O.V. Potential contribution of strigolactones in regulating scion growth and branching in grafted grapevine in response to nitrogen availability. J. Exp. Bot. 206, 2018.

102. RUYTER-SPIRA C., AL-BABILI S., VAN DER KROL S., BOUWMEESTER $\mathrm{H}$. The biology of strigolactones. Trends Plant Sci. 18, 72, 2013.

103. STIRNBERG P., WARD S., LEYSER O. Auxin and strigolactones in shoot branching: intimately connected? Biochem Soc Trans. 38, 717, 2010.

104. MISHRA S., UPADHYAY S., SHUKLA R.K. The Role of Strigolactones and Their Potential Cross-talk under Hostile Ecological Conditions in Plants. Front Physiol. 7, 691, 2016

105. NISAR N., LI L., LU S., CHIKHIN N., POGSON B.J. Carotenoid Metabolism in Plants. Molecular Plant. 8 (1), 68, 2015.

106. ALDER A., JAMIL M., MARZORATI M., BRUNO M., VERMATHEN M., BIGLER P., GHISLA S., BOUWMEESTER H., BEYER P., AL-BABILI S. The path from $\beta$-carotene to carlactone, a strigolactone-like plant hormone. Science. 335, 1348, 2012.

107. ESER A., AYDEMIR T. The effect of kinetin on wheat seedlings exposed to boron. Plant Physiol Biochem. 108, 158, 2016.

108. CARDOSO C., ZHANG Y., JAMIL M., HEPWORTH J., CHARNIKHOVA T., DIMKPA S.O., MEHARG C., WRIGHT M.H., LIU J., MENG X. Natural variation of rice strigolactone biosynthesis is associated with the deletion of two MAX1 orthologs. Proc Natl Acad Sci USA 111, 2379, 2014.

109. DELAUX P.M., XIE X., TIMME R.E., PUECH-PAGES V., DUNAND C., LECOMPTE E., DELWICHE C.F., YONEYAMA K., BÉCARD G., SÉJALON-DELMAS N. Origin of strigolactones in the green lineage. New Phytol. 195, 857, 2012. 
110. BU Q., LV T., SHEN H., LUONG P., WANG J., WANG Z. Regulation of drought tolerance by the F-Box protein MAX2 in Arabidopsis. Plant Physiol. 164, 424, 2014.

111. WOO H.R., KIM J.H., NAM H.G., LIM P.O. The delayed leaf senescence mutants of Arabidopsis, ore1, ore3, and ore9 are tolerant to oxidative stress. Plant Cell Physiol. 45, 923, 2004.

112. KOLTAI H. Strigolactones are regulators of root development. New Phytol. 190, 545, 2011.

113. KOLTAI H, KAPULNIK Y. Strigolactones as mediators of plant growth responses to environmental conditions. Plant Signal Behav. 6, 37, 2011.

114. GILROY S., JONES D.L. Through form to function: root hair development and nutrient uptake. Trends Plant Sci. 5, 56, 2000.

115. PANDEY A., SHARMA M., PANDEY G.K. Emerging Roles of Strigolactones in Plant Responses to Stress and Development. Front Plant Sci. 7, 434, 2016.

116. MARQUEZ-GARCIA B., NJO M., BEECKMAN T., GOORMACHTIC S., FOYER C.H. A new role for glutathione in the regulation of root architecture linked to strigolactones. Plant Cell Environ. 37, 488, 2014.

117. RAMAKRISHNA B., RAO S.S. Foliar application of brassinosteroids alleviates adverse effects of zinc toxicity in radish (Raphanus sativus L.) plants. Protoplasma, 252, 665, 2015.

118. RAMAKRISHNA B., SEETA RAM RAO S. Preliminary studies on the involvement of glutathione metabolism and redox status against zinc toxicity in radish seedlings by 28-Homobrassinolide . Environ Exper Bot, 96, 52, 2013.

119. HAYAT S., HASAN S.A., HAYAT Q., AHMAD A. Brassinosteroids protect Lycopersicon esculentum from cadmium toxicity applied as shotgun approach. Protoplasma, 239, 3, 2010.

120. RADY M.M. Effect of 24-epibrassinolide on growth, yield, antioxidant system and cadmium content of bean (Phaseolus vulgaris L.) plants under salinity and cadmium stress. Sci Hort. 129, 232, 2011.

121. ANURADHA S., RAO S.S.R. The effect of brassinosteroids on radish (Raphanus sativus L.) seedlings growing under cadmium stress. Plant Soil Environ. 5, 465, 2007.

122. HASAN S.A., HAYAT S., AHMAD A. Brassinosteroids protect photosynthetic machinery against the cadmium induced oxidative stress in two tomato cultivars. Chemosphere. 84, 1446, 2011.

123. MIR M.A., JOHN R., ALYEMENI M.N., ALAM P., AHMAD P. Jasmonic acid ameliorates alkaline stress by improving growth performance, ascorbate glutathione cycle and glyoxylase system in maize seedlings. Sci. Rep. 8, 2831, 2018.

124. PER T.S., KHAN N.A., MASOOD A., FATMA M. Methyl Jasmonate Alleviates Cadmium-Induced Photosynthetic Damages through Increased S-Assimilation and Glutathione Production in Mustard. Front Plant Sci. 22 (7), 1933, 2016.

125. AHMAD P., ALYEMENI M., VIJAYA L., ALAM P., ABASS M., ALAMRI S. Jasmonic acid alleviates negative impacts of cadmium stress by modifying osmolytes and antioxidants in faba bean (Vicia faba L.). Arch Agron Soil Sci. 63, 1889, 2017.

126. TIAN B., ZHANG Y., JIN Z., LIU Z., PEI Y. Role of hydrogen sulfide in the methyl jasmonate response to cadmium stress in foxtail millet. Front Biosci (Landmark Ed), 22, 530, 2017.

127. TAI Z., YIN X., FANG Z., SHI G., LOU L., CAI Q. Exogenous GR24 Alleviates Cadmium Toxicity by Reducing Cadmium Uptake in Switchgrass (Panicum virgatum) Seedlings. Int J Environ Res Public Health. 14, 2017.

128. SUN H., TAO J., LIU S., HUANG S., CHEN S., XIE X., YONEYAMA K., ZHANG Y., XU G. Strigolactones are involved in phosphate- and nitrate-deficiency-induced root development and auxin transport in rice. J Exp Bot. 65, 6735, 2014.

129. FOO E., YONEYAMA K., HUGILL C.J., QUITTENDEN L.J., REID J.B. Strigolactones and the Regulation of Pea Symbioses in Response to Nitrate and Phosphate Deficiency. Mol Plant. 6, 76, 2013.

130. KAPULNIK Y., KOLTAI H. Strigolactones Are Involved in Root Response to Low Phosphate Conditions in Arabidopsis. Plant Physiol. 160, 1329, 2012.

131. MAYZLISH-GATI E., DE-CUYPER C., GOORMACHTIG S., BEECKMAN T., VUYLSTEKE M., BREWER PB., BEVERIDGE CA., YERMIYAHU U., KAPLAN Y., ENZER Y., WININGER S., RESNICK N., COHEN M., KAPULNIK Y., KOLTAI H. Strigolactones are involved in root response to low phosphate conditions in Arabidopsis. Plant Physiol . 160 (3), 132941, 2012.

132. UMEHARA M., HANADA A., MAGOME H., TAKEDA-KAMIYA N., YAMAGUCHI S. Contribution of Strigolactones to the Inhibition of Tiller Bud Outgrowth under Phosphate Deficiency in Rice. Plant Cell Physiol. 51, 1118, 2010. 